\title{
Liposome Drug Delivery in Cancer Chemotherapy: Review and Multifactorial Analysis
}

\author{
Tatiara Régis ${ }^{1 *}$; Luciana Knop²; Bruna Machado²; Valter de Senna ${ }^{3}$ \\ ${ }^{1}$ SENAI CIMATEC, Doctorate Computational Modelling and Industrial Technology; ${ }^{2}$ SENAI CIMATEC, Technology \\ Institute of Health; ${ }^{3}$ SENAI CIMATEC, Computational Modelling and Industrial Technology; Salvador, Bahia, Brazil
}

\begin{abstract}
We reviewed the use of liposomes for cancer therapy using computational biostatistics. We used virtual libraries, such as PubMed, LILACS, National Health Institute (NHI) and the Food Drug Administration (FDA) to conduct the review. Cluster analysis and correlation were developed using the Tanimoto coefficient (TC) of 0.7 using the modeling tool ChemMine Tools from databases (PubChem, DailyMed, DrugBank, Drug @ FDA). The results pointed fifteen molecules in the pharmaceutical form of liposome for the oncological clinic. Of these, 13 are classified by size into small-molecules and were analyzed by computational statistical modeling. Of these, only 4 were approved for use by the FDA, and 9 are in phases of research by the pharmaceutical industry as liposomal formulations. Essential differences in physical-chemical properties and molecules structure were observed, indicating original proposal in the development of liposomal as an anticancer drugs.
\end{abstract}

Keywords: Bioinformatics. Cancer. Drug delivery. Liposomal.

The cancers have in common the disordered and malignant growth of several cell lines with the capacity to invade other tissues far from the place of origin, forming secondary tumors or metastases [1]. The disease is currently one of the world's public severe health problems. According to Globocan 2018, a project by the International Agency for Research on Cancer (IARC) of the World Health Organization (WHO), there were 14.7 million new cases of cancer and a total of 9.8 million cancer deaths worldwide in 2018, and a projection of almost 21.4 million new cases until 2030 with 13.2 million cancer deaths [2].

So, new antitumoral drugs are in tests as well as new methods to deliver these drugs. Due to the limitations and toxic events of conventional chemotherapies, several nanocarrier delivery systems have been developed and extensively used for drug delivery to cancer cells [3-5]. A large number of nanocarriers such as liposomes, polymeric nanoparticles, micelles, nanotubes, are already in the market, or under research and

Received on 17 February 2019; revised 23 February 2019. Address for correspondence: Dr. Tatiara Regis. Avenida Orlando Gomes, N. 1845, Piatã, Zip code: 41.650-010; Salvador, Bahia, Brazil. E-mail: tatiararegis3@gmail.com.

J Bioeng. Biotech. Appl. Health 2019;2(2):59-69.

(C) 2019 by SENAI CIMATEC. All rights reserved. evaluation for cancer treatment [6]. Reports reveal an estimated global growth of liposome drug delivery (LDD) around $\$ 3.6$ billion by 2020 in the global economic market and pharma industry [7].

The structural diversity and encapsulated drugs, as well as the mechanics of action liposomes, created a new technological perspective. However, there are challenges in methods for the preparation of liposomes, methods for efficient drug delivery, and procedures for the entrapment the drugs in the liposome. So, the innovations in liposome technology target researching that make it possible to predict new formulations and drugs for antitumoral treatments.

This review summarizes the types of methods used for the preparation of liposomes, mechanism of drug loading and potential therapeutic applications in cancer therapy, and provide current information on the liposomal products as a potent anticancer delivery drugs, either in clinical use or in clinical trials.

\section{Liposomes}

Liposomes have been widely used for several therapeutic applications, primarily as delivery drugs to reduce the toxic effects in the standard cell. They have also been used to optimize the bioavailability 
of drugs in areas such as pharmacology, oncology, cell biology, immunology, genetic engineering, and therapeutic and preventive medicine.

Liposomes have a larger surface area as compared to bigger particles, which can be easily modified to encapsulate a high amount of drug, increasing the blood circulation time, and enhancing the accumulation of drugs in solid tumors by permeability and retention (EPR) effect as well as selective targeting of tumor cells [8-10]. They also improve the solubility, bioavailability and pharmacokinetic properties of chemotherapeutics $[9,11,12]$.

Liposomes have an unusual sphere structure, globular lipid bilayers of 50-1,000 nm. They are versatile, notably in size, surface charge and have phospholipid bilayer membranes similar to plasmatic membranes, which favored the permeability of the molecules to get into the cell [13]. Therefore, these structures can encapsulate and deliver both hydrophilic and hydrophobic substances.

\section{Drug Delivery Systems (DDS)}

DDS are methods of administering drugs to reduce side effects and increase therapeutic efficacy, such as reduction of toxicity for anticancer agents [7,13]. DDS represents an advance in pharmaceutical technology compound to achieve a therapeutic effect in drug delivery for several treatments $[13,14]$.

Liposomes are a potential DDS [15] (Figure 1). For example, niosome are non-ionic surfactant vesicles obtained on hydration of synthetic nonionic surfactants, with or without incorporation of cholesterol or their lipids [16] by sub-micron (colloidal) of types MLVs (size $\geq 0.05 \mu \mathrm{m}$ ), LUVs ( size $\geq 0.10 \mu \mathrm{m})$, SUVs ( size $=0.025-0.05 \mu \mathrm{m})$ [17], and consist of advanced DDS liposome (Figure 2) [18].

Gregoriadis and colleagues [19] consider two aspects that justify the promising future of liposomes drug delivery (LDD): reducing toxic side effects, and incoming of the drug in tumor cells. The studies by liposomes have been showing that the absorption of the drug by tumor cells is superior to drugs used in chemotherapies [20].

\section{Designing Liposomes Drug Delivery (LDD)}

The physicochemicalproperties of the liposomes are generally useful for characterizing a drug formulation, which must be more stable to avoid changes in product quality, including leakage of the drug. So, chemical, manufacturing and control (CMC); pharmacokinetics and bioavailability; and labeling documentation for liposome products submitted to new drug applications (NDAs) and abbreviated to new drugs (ANDAs) have been reviewed by the Center for Drug Evaluation and Research (CDER) [21] and recommended by the FDA for Industry.

The production of liposomes involves the use of an active agent and a phase lipid/lipid drug. So, the variety of natural or synthetic lipids, the different sizes, and molar rays, lead to a diversity of liposomes. In this aspect, the inherent properties of the carriers' structures and the nature of the drug to be encapsulated could affect biological half-life and modify drug absorption due to the relation between such structures and physicochemical characteristics of the drug substance (Table 1) [22].

At present, the designing stage of the liposome is still in the beginning. So, the choice of the

Figure 1. Illustration of liposome for drug delivery.

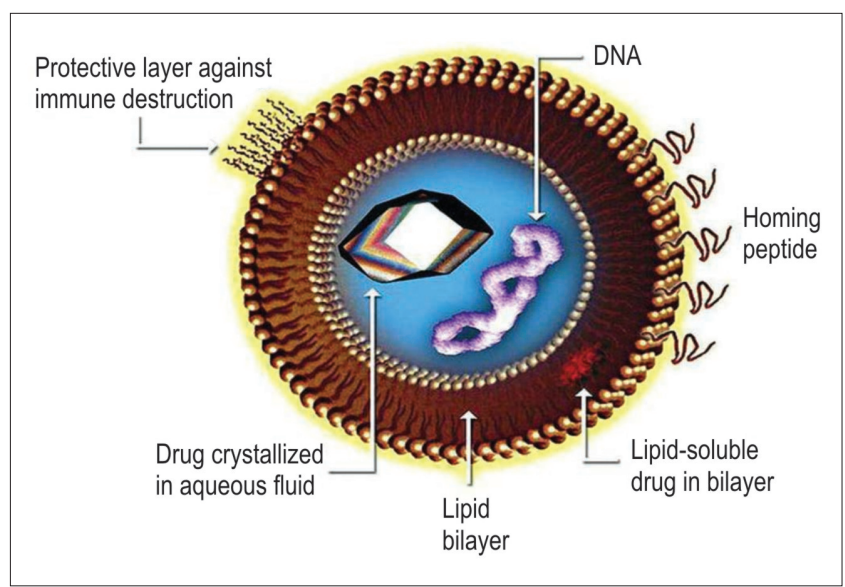

Source: Çağdaş M. et al. (2010) [15]. 
Figure 2. A schematic structures of non-ionic surfactant vesicle.

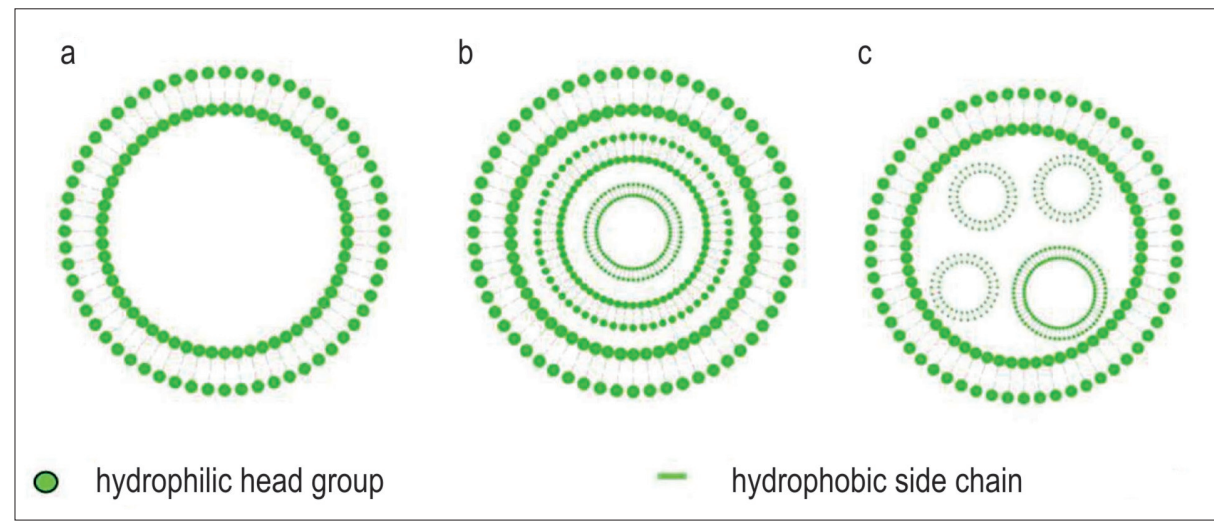

(a) unilamellar vesicle, (b,c). multi-lamellar vesicle [18].

best liposome design and reagent quality may be decisive for the testing phases for drug approval.

\section{Liposomes Drug Delivery in Cancer}

FDA approvals 16 news therapies for cancer with new pharmaceuticals, including new molecular entities (NMEs) and new Biologic License Applications (BLAs) between 20132016. The pipeline of 836 drugs for cancer using liposomes in 2016, 123 were for lung cancer, 106 for leukemia, 92 for lymphoma (including nonHodgkin lymphoma), 82 for breast cancer, 58 for brain tumors, 53 for skin cancer (including melanoma) [23].

According to Institute for Healthcare Informatics (IMS) on Global Use of Drugs [24], many potential applications of liposomes in immunotherapies and targeted therapies will be a promising field in oncology and drug delivery in 2020 [25].
Regarding clinically used liposome-based products in cancer chemotherapy active agent indicated for the treatment of different types of cancer are Doxorubicin (DOX) (Doxil@/ Myocet ${ }^{\circledR}$ ), Daunorubicin (DAU) (DaunoXome ${ }^{\circledR}$ ), Cytarabine/Ara-C (Depocyt $\left.{ }^{\circledR}\right), \quad$ Mifamurtide (Mepact $\left.{ }^{\circledR}\right)$, Vincristine (Marqibo () , Irinotecan (Onivyde ${ }^{\mathrm{TM}}$ ). Also, the pharmaceutical industry is testing for some new active substance (NAS) Tecemotide, T4 endonuclease V, Cisplatin, Lurtotecan, Paclitaxel, all-trans retinoic acid for treating different types of cancer [26]. For example, Idarubicin (IDA), a drug exclusively used for the treatment of leukemia through thermosensitive liposomes (TSL) in combination with hyperthermia (HT) demonstrated to be more prominent tumor growth inhibition in leukemia than in the conventional form [27].

Some of these drugs have already in Phase II in Japan, as Stimuvax ${ }^{\circledR}$ (Tecemotide/L-BPL

Table 1. Effect of the nature of the drug on the formation of niosomes.

\begin{tabular}{llll}
\hline Nature of drug & Leakage from the vesicle & Stability & Oher properties \\
\hline Hydrophobic drug & Decreased & Increased & Improved transdermal delivery \\
Hydrophilic drug & Increased & Decreased & - \\
Amphiphilic drug & Decreased & - & $\begin{array}{l}\text { Increased encapsulation, } \\
\text { altered electrophoretic mobility }\end{array}$ \\
& & & - \\
\hline
\end{tabular}

Modified from KM Kazi et al. (2010) [22]. 
25) [28]: a liposome vaccine against the cancer cells that overexpress Mucin 1 (MUC-1) (Figure 3 ), a glycoprotein antigen expressed in cancers such as multiple myeloma and colorectal, breast cancer, prostate and ovarian cancers. However, the results of Stimuvax ${ }^{\circledR}$ were disappointing to the investigational therapeutic vaccine to enter Phase III (PhIII) studies in Non-Small Cell Lung Cancer (NSCLC), mainly due to flops in Phase III lung cancer trial and breast tumors [28-30]. Even so, the pharmaceutical company, Merck, will be responsible for the clinical development, commercial producing and marketing, estimated the sales to reach about $€ 350 \mathrm{~m}$ in 2019 [28].

Pfizer developed and produced the drug Xalkori ${ }^{\circledR}$ (Crizotinib) [31] for the treatment for Non-Small Cell Lung Cancer (NSCLC) and metastatic anaplastic lymphoma kinase (ALK) approved by FDA in August 2011 using liposomes [32]. Crizotinib is a receptor tyrosine kinase inhibitor that inhibits ALK and c-MET, and it is also been using in a liposome as a targetantitumoral drug [33,34].

Darolutamide by Bayer and Orion [33] have reported positive results in Phase III clinical trial (ARAMIS) in patients with non-metastatic castration-resistant prostate cancer using liposomes [35].
Avapritinib, an inhibitor of KIT and PDGFR $\alpha$ $\mathrm{D} 842 \mathrm{~V}$ mutant kinases, is under clinical development in China at present (2019) for GI Stromal tumors $[33,36]$.

Analysis of Liposome Drug Delivery in Anticancer Therapy

We performed a database of chemical molecules, substances, compounds, bioassay, drugs and drugs for therapeutic or clinical medicine in liposomes using (PubChem) (National Institutes of Health - NIH), DailyMed [37], DrugBank [38,39], Drug@FDA [40], Pubmed (Medline), Cochrane Foundation, Isi Web of Science. Our focus was to find molecular similarities and correspondence for both liposome drug and drug delivery molecule for anticancer therapies, both approved and already in use, as well as those that are released by the FDA for in phases 3,2,1 or investigative research.

Fifteen molecules were found in the pharmaceutical form of liposome for oncological clinic. Of these, 13 are classified by size into smallmolecules and were analyzed by computational statistical modeling. Of these only four were approved for use by the FDA, and nine are in phases of research by the pharmaceutical industry as liposomal formulations (Table 2). Tecemotide (Stimuvax $\left.{ }^{\circledR}\right)$, Vincristine (Marquibo $\left.{ }^{\circledR}\right)$, and

Figure 3. Proposed mode of action of L-BPL 25.

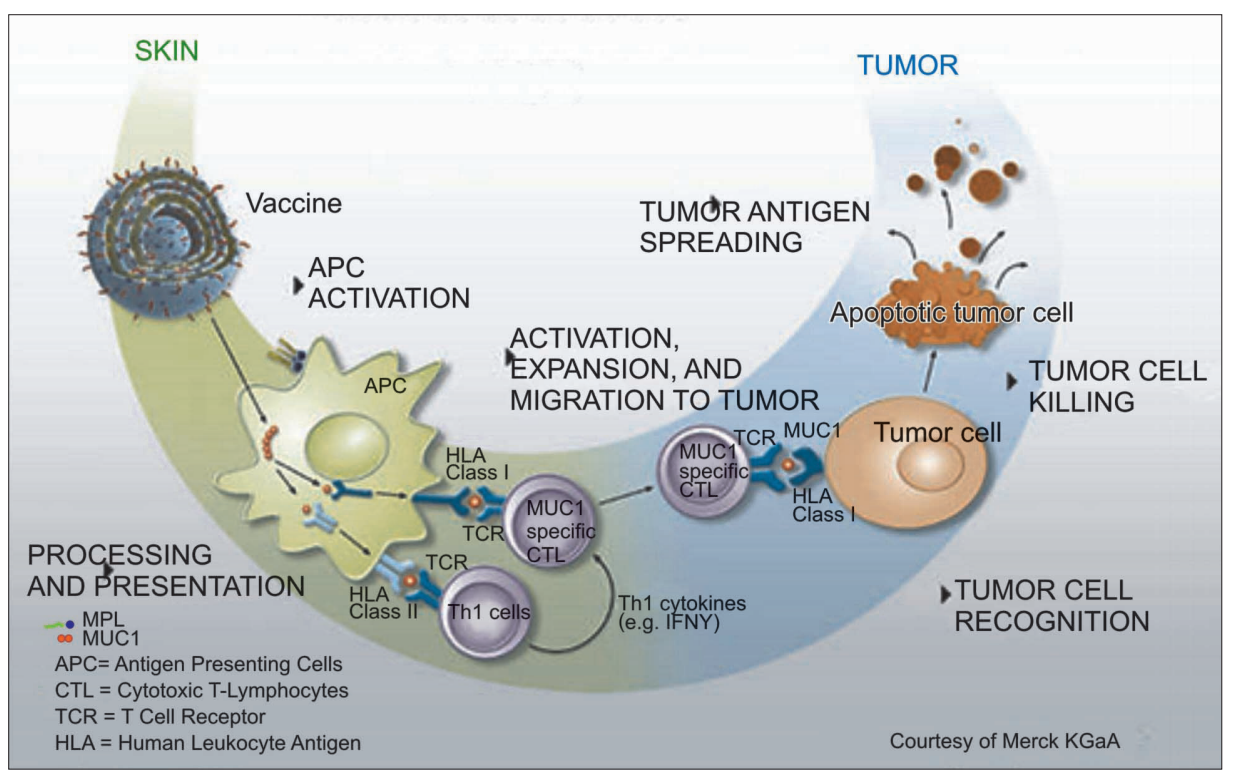


Table 2. Therapy and anticancer LDD approved by FDA and in investigative research.

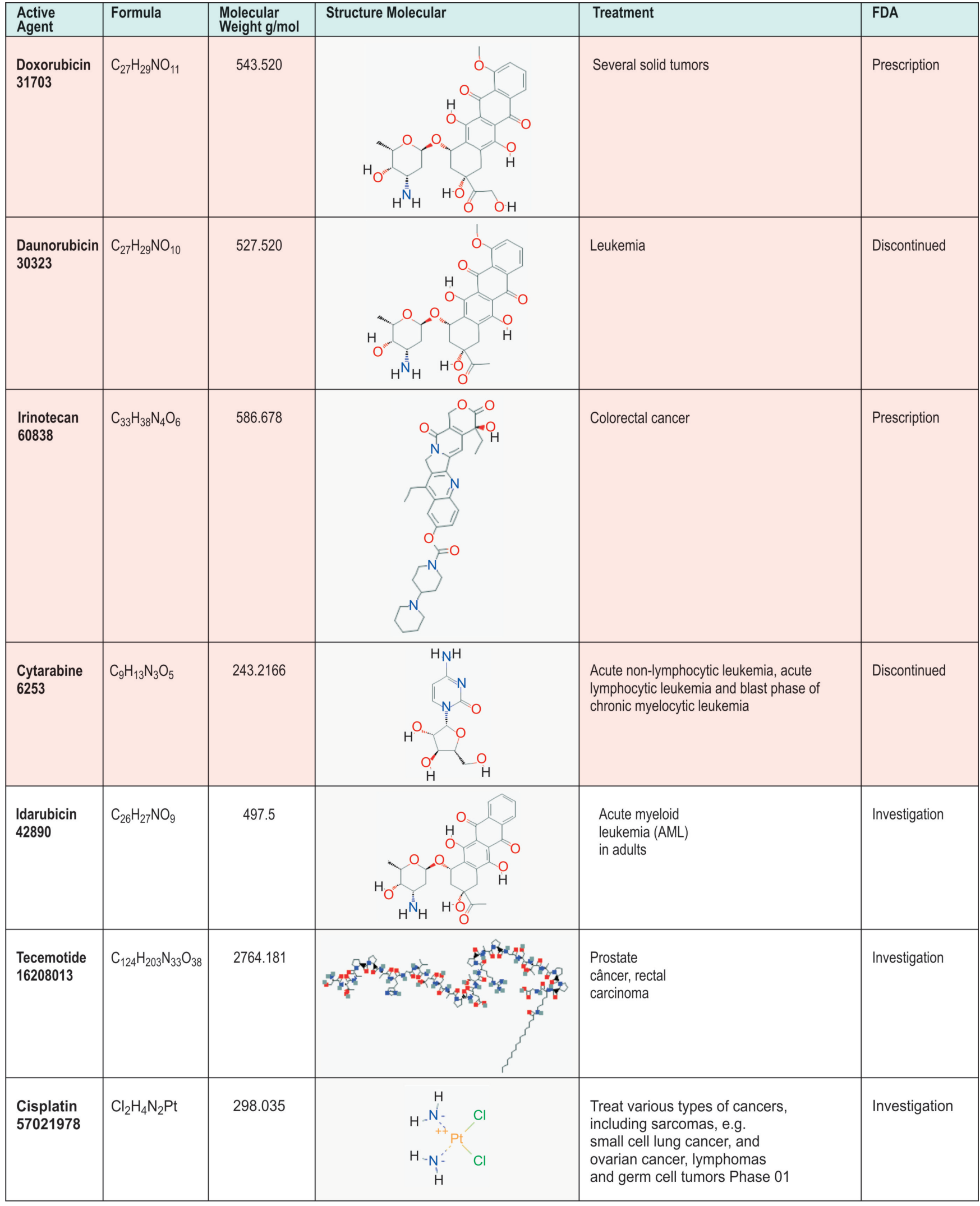

The pink's lines is active agent approved FDA and used liposome-based products for treatment various types of cancer. 


\section{(continued Table 2)}

\begin{tabular}{|c|c|c|c|c|c|}
\hline $\begin{array}{l}\text { Active } \\
\text { Agent }\end{array}$ & Formula & $\begin{array}{l}\text { Molecular } \\
\text { Weight } \mathrm{g} / \mathrm{mol}\end{array}$ & Structure Molecular & Treatment & FDA \\
\hline $\begin{array}{l}\text { Lurtotecan } \\
60956\end{array}$ & $\mathrm{C}_{28} \mathrm{H}_{30} \mathrm{~N}_{406}$ & 518.57 & & $\begin{array}{l}\text { Antineoplastic } \\
\text { activity }\end{array}$ & $\begin{array}{l}\text { Investigation / } \\
\text { BioAssay }\end{array}$ \\
\hline $\begin{array}{l}\text { Paclitaxel } \\
36314\end{array}$ & $\mathrm{C}_{47} \mathrm{H}_{51} \mathrm{NO}_{14}$ & 853.918 & & $\begin{array}{l}\text { Carcinoma of the ovary, and other } \\
\text { various cancers including } \\
\text { breast cancer }\end{array}$ & $\begin{array}{l}\text { Investigation } \\
\text { for liposome } \\
\text { form }\end{array}$ \\
\hline $\begin{array}{l}\text { All-trans Acid } \\
\text { Retinoic } \\
444795\end{array}$ & $\mathrm{C}_{20} \mathrm{H}_{28} \mathrm{O}_{2}$ & 300.442 & & Acute promyelocytic leukemia (APL) & Investigation \\
\hline $\begin{array}{l}\text { Crizotinib } \\
11626560\end{array}$ & $\mathrm{C}_{21} \mathrm{H}_{22} \mathrm{Cl}_{2} \mathrm{FN}_{5}$ & 450.339 & & Non-small cell lung cancer & Prescribed \\
\hline $\begin{array}{l}\text { Darolutamide } \\
67171867\end{array}$ & $\mathrm{C}_{19} \mathrm{H}_{19} \mathrm{ClN}_{6} \mathrm{O}_{2}$ & 398.851 & & Prostate câncer & Descontinued \\
\hline $\begin{array}{l}\text { Avapritinib } \\
118023034\end{array}$ & $\mathrm{C}_{26} \mathrm{H}_{27} \mathrm{FN}_{10}$ & 498.57 & & & Investigation \\
\hline
\end{tabular}


Mifamurtide (Mepact $\left.{ }^{\circledR}\right)$ were not evaluated in this analysis.

We use ChemMine ${ }^{\circledR}$ for small molecules data analysis relevant in chemical biology, chemical genomics, and drug discovery [41]. ChemMine ${ }^{\circledR}$ proved to be an excellent software to study similarity, clustering, prediction of a small molecule, integrating the physicochemical and bioactivity properties through PubMed [42].

Few similarities are found between the liposome-based products in Cancer Chemotherapy approved (Graphic 1). So, the diversity physicochemical characteristics of a drug molecule in terms of therapeutic class and chemical structures, involving different functional groups are factors considered essential to meet FDA recommendations about liposomes as a tool with anticancer drugs.

The graphics multidimensional scaling(MDS) is an array of item distances. The coordinates are assigned to each item in a low-dimensional space to represent the distances graphically in a scatter plot.

The distance matrices required for the clustering of MDS were calculated by comparisons of all against all compounds using measures of similarity of atom pairs, the similarity of substructures and transforming similarity scores generated in distance values. According to the model proposed by ChemMine $\AA$, basic descriptor type that is defined by the shortest paths among the non-hydrogen atoms in a molecule are atom pair. The TC calculated the similarity and the distance values were calculated by subtraction $(1-T c)$. Then, the coordinates are assigned to each item in a low-dimensional space to plot the distances in a scatter plot. We determined $\mathrm{Tc}=0.7$. The coefficient varies between $0-1$, the higher, the greater, and the greater the similarity. The axes V1 and V2 represent the chemical space in two directions. A higher correlation between the structures contained in the pink band on Graphic 2 .
HC results were developed based on the molecular weight and physicochemical properties heat map Joe Lib descriptors. The JOELib tool computes 38 descriptors for each compound. The result showed the most similar of all molecular, almost identical is cluster hierarchical formed by DOX/ DAU and IDA. IDA is closer in physicochemical properties of DAU than dox. DAU has been discontinued for economic issues unrelated to the product's quality, safety or efficacy.

Boron (B), Bromine (B), Iodine (I), Phosphorus (P), Sulfur (S), SO2, -SO2, -OSO, $-\mathrm{NO} 2$, and hydrophilic groups are not present in all active agents.

The molecular weight, an import characteristic for liposome development varies in green range by almost all molecules, except Cytarabine, All-trans- Acid retinoic, Darulutamide and Paclitaxel.

Several halogen atoms are down (blue for green), but more in the cluster formed by Crizotinib, Daurulutamide, and Avapritinib.

The number of primary groups and acid groups between the active agents, Lurtotecan showed the most significant amount of basics groups. However, with the predominance of acid groups, eight of the fifteen compounds analyzed contained more acid groups, highlighting all trans-acid-retinoic.

Lurtotecan and Irinotecan were outside the correlation range due to out of the correlation range due to the presence of a primary group in the first and greatest geometrical diameter in second. On the other hand, Cytarabinestands out from all other compounds by having lower: molecular weight, P-hydroxybenzaldehyde, heavy bonds, number of atoms, number of bonds, geometrical diameter, and other descriptors.

\section{Conclusion}

The use of liposome as anticancer therapy is restricted. However, liposomes are an essential research niche for NAS prospecting 
Graphic 1. Multidimensional Scaling Clustering (MDS) of the NAS liposome in clinical oncology.

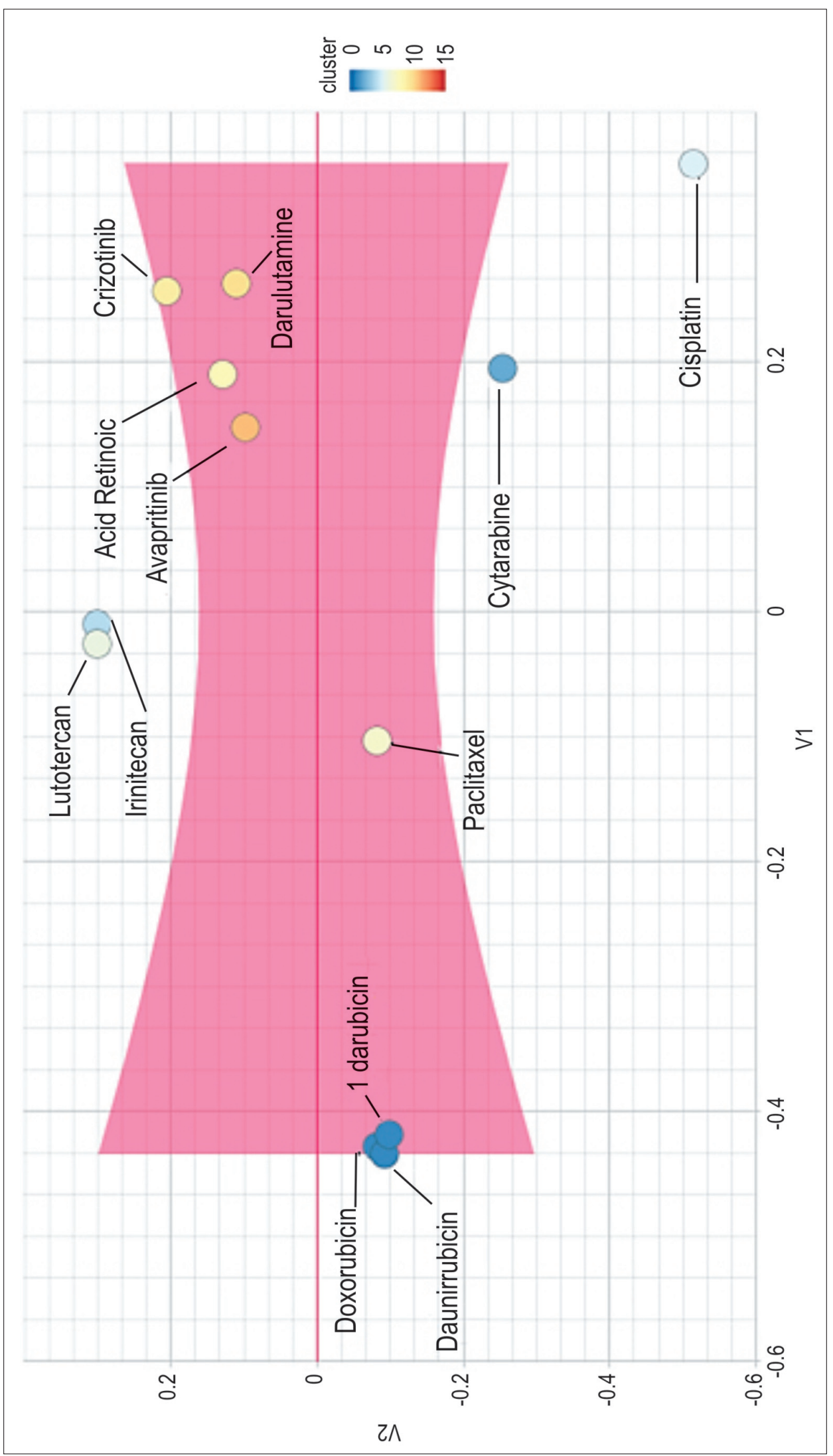


Graphic 2. Hierarchical Clustering Results of the NAS liposome in clinical oncology.

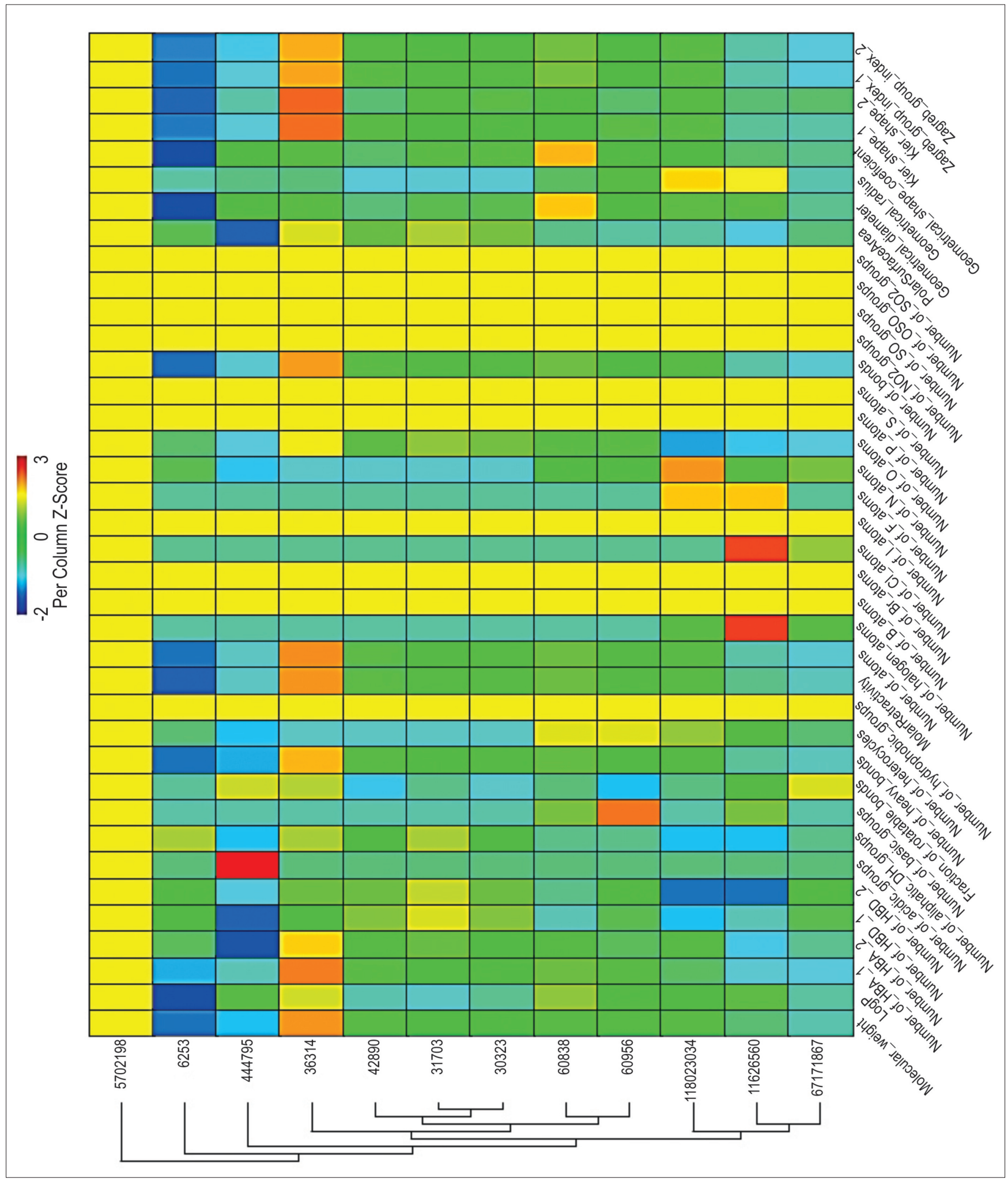


in which the evaluation of the physical and chemical characteristics of the pharmaceutical by computational methods can provide valuable information for the development of LDD in antineoplastic therapy. Nevertheless, it is essential to make a point of time-based understanding of physicochemical and bioactivity properties may be useful in finding methods of predicting more assertive experimental bed paths.

\section{References}

1. INCA. Estimativa do câncer para 2017. Boletim. Disponível em: www.inca.gov.br. Acessado em 26 de março de 2017.

2. Globocan 2018 v1.0, Cancer Incidence and Mortality Worldwide: IARC Cancer Base No. 11 [Internet]. Lyon, France: International Agency for Research on Cancer; 2016. Available from: http://globocan.iarc.fr, accessed on $10 / 06 / 2018$.

3. Tyagi, N., Ghosh, P.C. Folate receptor mediated targeted delivery of ricin entrapped into sterically stabilized liposomes to human epidermoid carcinoma (KB) cells: effect of monensin intercalated into folate-tagged liposomes. Eur J Pharm Sci. 2011;43:343-53.

4. Tyagi, N., Rathore, S.S., Ghosh, P.C. Enhanced killing of human epidermoid carcinoma (KB) cells by treatment with ricin encapsulated into sterically stabilized liposomes in combination with monensin. Drug Deliv. 2011;18:394-404.

5. Arora, S., Tyagi N., Bhardwaj, A. et al. Silver nanoparticles protect human keratinocytes against UVB radiation-induced DNA damage and apoptosis: potential for prevention of skin carcinogenesis. Nanomedicine. 2015;11:1265-75.

6. Sutradhar, K.B., Lutful, A. Nanotechnology in Cancer Drug Delivery and Selective Targeting. ISRN Nanotech. 2014: 939378. doi: 10.1155/2014/939378.

7. NHI National Institute of Biomedical Imaging and Bioengineering. About: Drug Delivery Systems. Website: NHI National Institute of Biomedical Imaging and Bioengineering, October 2016. Disponivel em: $<$ https://www.nibib.nih.gov/science-education/sciencetopics/drug-delivery-systems $>$. Acesso em: 19 Feb 2019.

8. Tyagi $\mathrm{N}$ and Ghosh PC. Folate receptor mediated targeted delivery of ricin entrapped into sterically stabilized liposomes to human epidermoid carcinoma (KB) cells: effect of monensin intercalated into folatetagged liposomes. Eur J Pharm Sci. 2011; 43: 343-353.

9. Bozzuto, G., Molinari, A. Liposomes as nanomedical devices. Int J Nanomedicine. 2015;10:975-99.
10. Allen, T.M., Cullis, P.R. Liposomal drug delivery systems: from concept to clinical applications. Adv Drug Deliv Rev. 2013;65:36-48.

11. Gregoriadis, G., Florence, A.T. Liposomes in drug delivery. Clinical, diagnostic and ophthalmic potential. Drugs. 1993;45:15-28.

12. Pattni, B.S., Chupin, V.V., Torchilin, V.P. New Developments in Liposomal Drug Delivery. Chem Rev. 2015;a:A

13. Tiwari, E.A. Drug delivery systems: An updated review. International Journal of Pharmaceutical Investigation. 2012;2(1). Disponivel em: <www.jpionline.org>.

14. Coelho, J.F.P. Drug delivery systems: Advanced technologies potentially applicable in personalized treatments. EPMA Journal 2010;1(20):164-209.

15. Çağdaş, M., Sezer, A.D., Bucak, S. Liposomes as Potential Drug Carrier Systems for Drug. [S.l.]: [s.n.], 2014. Cap. 1, p. 1-50. Disponivel em: <https://www. intechopen.com/books/application-of-nanotechnologyin-drug-delivery/liposomes-as-potential-drug-carriersystems-for-drug-delivery>.

16. Usman, E.A. Niosomes: A Novel Trend of Drug Delivery. EJBPS European Journal of Biomedical. 2017;4,(7)17:436-42. Disponivel em: <http://www. ejbps.com>. SJIF Impact Factor 4.382.

17. More, E.A. Niosome: Comprehensive review. Asian Journal of Pharmaceutics. 2018;12(4).

18. Ge, X. et al. Advances of non-ionic surfactant vesicles (niosomes) and their application in drug delivery. Pharmaceutics. 2019;29(1). Disponivel em: <https:// www.mdpi.com/1999-4923/11/2/55/htm>. Acesso em: 19 Feb 2019. Impact Factor: 3.746.

19. Poste, G., Kirsh, R., Koestler, T. Liposomes and drug delivery in cancer chemotherapy. In: GREGORIADIS, G. Liposome Technology: targeted drug delivery and biological interation. [S.1.]: CRC Revivals. 2018;(3):21-3.

20. Agarwal V., Rani, R., Pandey, H. Liposome and their applications in cancer therapy. Braz. arch. biol. technol. 2016;59(8). dx.doi.org/10.1590/1678-43242016150477.

21. Federal Register. About: liposome drug products guidance for industryFDA. Website: Federal Register: The Daily Journal of the United States Government, 2018. Disponivel em: <https://www.federalregister.gov/ documents/2018/04/05/2018-06926/liposome-drugproducts-chemistry-manufacturing-and-controls-humanpharmacokinetics-and $>$. Acesso em: 10 fev. 2019.

22. Kazi, K.M. Niosome: A future of targeted drug delivery systems. Articles from Journal of Advanced Pharmaceutical Technology \& Research, 1, Oct-Dec 2010. 374-380. Disponivel em: <https://www.ncbi.nlm. nih.gov/pmc/articles/PMC3255404/>. Acesso em: 19 Feb 2019. 
23. Buffery, D. Innovation Tops Current Trends in the 2016 Oncology Drug Pipeline. American health \& drug benefit, 2016. Disponivel em: <ncbi.nlm.nih.gov>.

24. Institute for Healthcare Informatics. Global Medicines Use in 2020. IMS Institute. [S.1.]. 2015.

25. Henrya, L., Haysb, D.F. Cancer biomarkers. Molecular Oncology, 2012:140-6. Disponivel em: <www.elsevier. com/locate/molonc $>$.

26. Bulbake, U., et al. Liposomal Formulations in Clinical Use: An Updated Review. Pharmaceutics. 2017;2(27). Disponivel em: <https://www.ncbi.nlm.nih.gov/ pubmed/28346375>.

27. Lu, T. Formulation and optimization of idarubicin thermosensitive liposomes provides ultrafast triggered release at mild hyperthermia and improves tumor response. Journal of Controlled Release. 2015;(3): 42537. Disponivel em: <journal homepage: www.elsevier. com/locate/jconrel>.

28. Drug Development. About: Stimuvax - Investigational Therapeutic Cancer Vaccine. Drud Development Technology, 2019. Disponível em: <https://www. drugdevelopment-technology.com/projects/stimuvax/>. Acesso em: 18 fev. 2019.

29. Fiercebiotec. About: Oncothyreon routed after Merck KGaA's Stimuvax flops in PhIII lung cancer trial. Website:FierceBiotech.2012;19(December).Disponível em: $<$ https://www.fiercebiotech.com/r-d/oncothyreonrouted-after-merck-kgaa-s-stimuvax-flops-phiii-lungcancer-trial>. Acesso em: 18 fev. 19.

30. Wurz, G.T.E.A. Tecemotide: An antigen-specific cancer immunotherapy. Human Vaccines \& Immunotherapeutics. 2014;10(11):3383-93. Disponível em: $\quad<$ https://www.ncbi.nlm.nih.gov/pmc/articles/ PMC4514140/pdf/khvi-10-11-974454.pdf>.

31. Pfizer. About: Xalkori product. Xalkori ${ }^{\circledR}$ crizotinibe 2018 (10) Jul. Disponível em: <https://www.pfizer. com.br/sites/g/files/g10044511/f/product_attachments/ Xalkori_PS.pdf $>$. Acesso em: 20 Feb 2019.

32. Drug Development. About: Xalkori - Treatment for Non-Small Cell Lung Cancer. Drug development Technology, 2019. Disponivel em: <https://www. drugdevelopment-technology.com/projects/xalkori--treatment-for-nonsmall-cell-lung-cancer/>. Acesso em: 18 fev. 2019.
33. Drug Development Technology. Bayer and Orion report positive data from trial of darolutamide. Website: Drug Development Technology, 18 February 2019. Disponivel em: <https://www.drugdevelopment-technology.com/ news/bayer-orion-darolutamide-aramis-trial/>. Acesso em: 18 February 2019.

34. Sahu,A. Crizotinib: A comprehensive review. South Asian Journal of Cancer. 2013;(2):91-7. Disponível em: <https:// www.ncbi.nlm.nih.gov/pmc/articles/PMC3876666/>.

35. Broderick, J.M. About: Darolutamide Improves MFS in Phase III Nonmetastatic CRPC Trial. Websit: OncoLive, 24 Oct 2018. Disponível em: <https://www.onclive. $\mathrm{com} /$ web-exclusives/darolutamide-improves-mfs-inphase-iii-nonmetastatic-crpc-trial>.

36. Pharmaceutical Quality/CMC. Liposome Drug Products: Chemistry, Manufacturing, and Controls; Human Pharmacokinetics and Bioavailability; and Labeling Documentation. U.S. Department of Health and Human Services, Food and Drug Administration (FDA), Center for Drug Evaluation and Research (CDER). [S.1.]. 2018.

37. National Institutes of Health (NIH). PubChemDocs. About: PubChem. Disponível em: <https://pubchem. ncbi.nlm.nih.gov/>. Acesso em: 14 Feb 2019.

38. NHI U.S. National Library of Medicine. About the Company: DailyMed. WebSiteDailyMed, 2017. Disponivel em: <https://dailymed.nlm.nih.gov/ dailymed/>. Acesso em: 15 Feb 2019.

39. Research Solutions, TMIC. About: DruBank. Website: DrugBank, 20 Dec 2018. Disponível em: <https://www. drugbank.ca/>. Acesso em: 15 Feb 2019.

40. U.S. Food and Drug Administration; U.S. Department of Health and Human Services. Website: Us Food \& Drug Administration. About: Drug, fev. 2019. Disponivel em: $<$ https://www.accessdata.fda.gov/scripts/cder/ob/index. $\mathrm{cfm}>$. Acesso em: $11 \mathrm{Feb} 2019$.

41. Backman, H., Cao, Y., Girke, T. ChemMine tools: an online service for analyzing and clustering small molecules. Nucleic Acids Research. 2011;39(20):48691.

42. National Center for Biotechnology Information, NHI NationalHealthInstitute.About:OpenChemistryDatabase. WebSite: PubChem. Disponível em: <https://pubchem. ncbi.nlm.nih.gov/bioassay/1259409\#section=Top $>$. Acesso em: 20 Feb 2019. 